\title{
Recruitment Age of Litopenaeus vannamei (Boone, 1931) (Decapoda: Penaeidae) in the Cabeza De Toro-La Joya Buenavista Lagoon System, Oaxaca-Chiapas, Mexico
}

\author{
Pedro Cervantes-Hernández ${ }^{1 *}$, Pablo Torres-Hernández², Mario Alejandro Gómez-Ponce ${ }^{3}$ \\ ${ }^{1}$ Institutos de Recursos, Universidad del Mar, Carretera a Zipolite, Puerto Ángel, México \\ ${ }^{2}$ Instituto de Industrias, Universidad del Mar, Carretera a Zipolite, Puerto Ángel, México \\ ${ }^{3}$ Instituto de Ciencias del Mar y Limnología, Universidad Nacional Autónoma de México (Estación El Carmen), \\ Ciudad del Carmen, México \\ Email: *pch@angel.umar.mx
}

How to cite this paper: CervantesHernández, P., Torres-Hernández, P. and Gómez-Ponce, M.A. (2017) Recruitment Age of Litopenaeus vannamei (Boone, 1931) (Decapoda: Penaeidae) in the Cabeza De Toro-La Joya Buenavista Lagoon System, Oaxaca-Chiapas, Mexico. Open Journal of Marine Science, 7, 511-525.

https://doi.org/10.4236/ojms.2017.74036

Received: September 26, 2017

Accepted: October 28, 2017

Published: October 31, 2017

Copyright $\odot 2017$ by authors and Scientific Research Publishing Inc. This work is licensed under the Creative Commons Attribution International License (CC BY 4.0).

http://creativecommons.org/licenses/by/4.0/ (c) (i) Open Access

\begin{abstract}
At present, the fishery of Litopenaeus vannamei continues overexploited in the Gulf of Tehuantepec (GT), Mexico. From the available literature it was demonstrated that marine closure systems implemented in GT have not worked adequately since 1993, because these are completely protecting marine recruitment seasons, and reproductive seasons were only partially considered to protect. Due to these problems, new marine closure systems were proposed in the literature, but they were not accepted by fishermen from GT because they did not include marine and lagoon recruitment information. For this reason, in this study both recruitment types were analyzed with estimations on the recruitment age $(R A)$, and its relationship with total length and weight. To the Cabeza de Toro la Joya Buenavista lagoon system (CTJB-LS), it was concluded that young recruits migration toward outside CTJB-LS elapsed between 3 and 5-m-olds, with the highest recruit flow in 4-m-olds. Thus, this last age was called the $R A$ of $L$. vannamei (at $106 \mathrm{~mm}$ ). Maximum marine recruitment ranked from June to July, and maximum reproductive seasons were in October. In both recruitment seasons it was observed that biomass production was different. In marine season $R A$ recorded $8.4 \mathrm{~g}$ more than lagoon season at the same size. Results were used in order to discus about atarraya nets uses, and to propose the implementation of a lagoon closure during July inside lagoon systems located in GT. With this proposal artisanal fishermen will be allowed to use atarraya nets with mesh opening of $25.4 \mathrm{~mm}$ during June, and they will obtain a good biomass production level as economic support.
\end{abstract}


Additionally, with new marine closure systems shrimp reproductive seasons will be protected (from July to November).

\section{Keywords}

Closure Systems, Gulf of Tehuantepec, Recruitment Age, Recruitment Seasons, White Shrimp

\section{Introduction}

The life history of the Penaeidae shrimps family is approximately between 15 and 18 months (Cervantes-Hernández, 2008 [1]), and this begins in the marine environment with the reproduction that generates shrimp post-larvae. After those enter lagoon systems for their protecting, feeding and growing until they are young shrimp (Gracia et al., 1997 [2]). When young shrimp reach a total length $\sim 80 \mathrm{~mm}$ they leave lagoon systems to return to the marine environment, and start life history again.

From the four commercial shrimp species that inhabit in the Gulf of Tehuantepec (GT), México (Figure 1), white shrimp Litopenaeus vannamei (Boone 1931) has been most studied species. For this shrimp population the following studies were done: mortality (Ramos-Cruz et al., 2006 [3]), exploitation evaluation

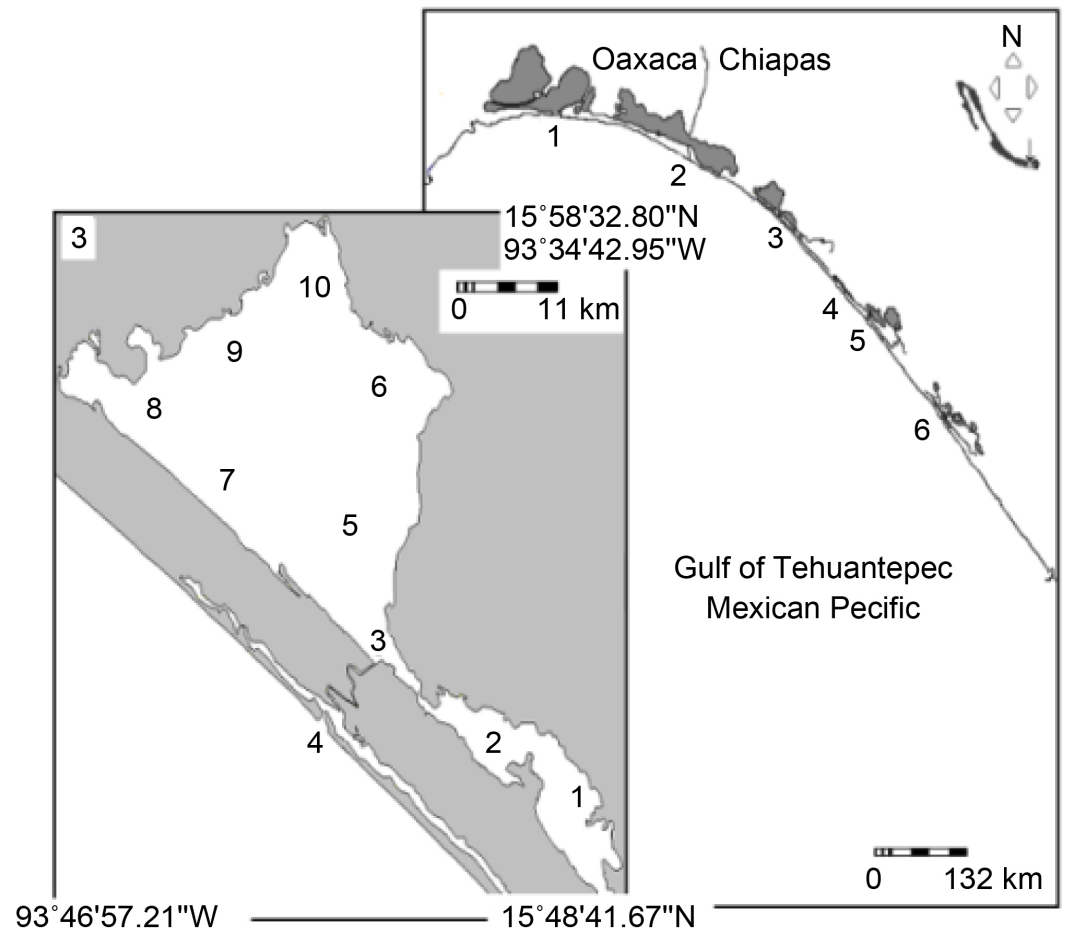

Figure 1. Geographic location of GT and the CTJB-LS. The lagoon systems from GT are: Huave (1), Mar Muerto (2), Cabeza de Toro la Joya Buena Vista (3), Patos Solo Dios (4), Carretas Pereyra (5), Chantuto Panzacola (6). Sampling stations are shown with the numbers from 1 to 10 . 
and closures (Cervantes-Hernández et al., 2008 [4]), reproductive and recruitment seasons (Cervantes-Hernández et al., 2008 [5]), and ecological distribution (Cervantes-Hernández and Egremy-Valdez, 2013 [6]). Based on the aforementioned literature, it was concluded:

1) The complete life history is approximately between 15 and 16 months (Cervantes-Hernández et al., 2008 [4]).

2) The "Marine Recruitment" was defined as the natural movement of young shrimp from inside lagoon systems towards the marine environment of GT (Cervantes-Hernández et al., 2012 [7]). In GT (Figure 1) a complete marine recruitment season spanned from April to August, with the highest recruit flow during June/July (Cervantes-Hernández et al., 2008 [4]).

3) The "Lagoon Recruitment" was defined as the natural movement of post-larvae shrimp from the marine environment of GT towards inside lagoon systems (Cervantes-Hernández et al., 2012 [7]). The white shrimp reproduces during the lagoon recruitment, and in the GT a complete lagoon recruitment season spanned from July to November, with the highest post-larvae flow during October (Cervantes-Hernández et al., 2008 [4]).

In the marine environment of GT, the recruitment age of white shrimp was estimated at 4-m-olds (Cervantes-Hernández et al., 2008 [4]), and inside CTJB-LS this age was reported between 4.5 and 5-m-olds (Cervantes-Hernández et al., 2012 [7]). It was found that recruitment age has not been clearly identified, and information about total length $(L t)$ corresponding to each mentioned recruitment age is scarcely documented. For the mentioned problems, at present, it has not been easy to implement the best fishing net selectivity with the adequate mesh opening (atarrayas) to protect this resource inside lagoon systems located in GT (Ramos-Cruz, 2011 [8]). In this study mesh opening theme was taken into account only in the discussions, because the aim of this study was to generate biological information to propose the implementation of a lagoon closure inside lagoon systems in GT. This specific information was the recruitment age and the biomass production during the marine and lagoon recruitment seasons.

In the present study, dwell times inside lagoon (TL) were accounted for re-estimating with more exactitude the recruitment age of white shrimp. For explanation, the seasonality of biomass changes were analyzed records of $L t$ (in $\mathrm{mm}$ ) and total weight ( $P t$ in gr). Finally, conclusions were made considering relationship between recruitment age and $L t-P t$.

This study took as initial point of analysis, the results of Cervantes-Hernández et al., 2012 [7] (Figure 2). For this reason, the present study was a continuation of this work. Obtained results and conclusions of this study are different to reported by these authors because they did not estimated TL and the seasonality of biomass changes.

\section{Materials and Methods}

For the present study, between April 25 2001 and March $28^{\text {th }} 2002$, technical 


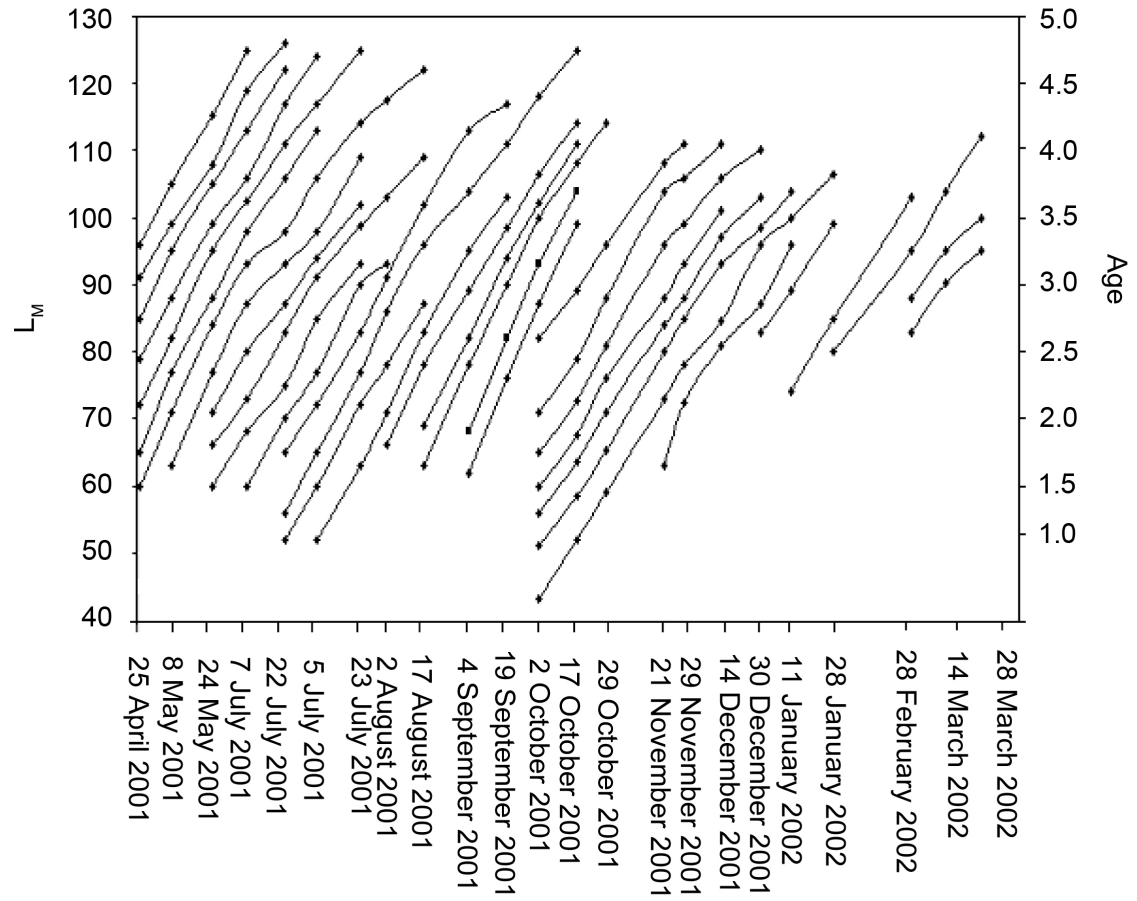

Figure 2. Modal progression analysis with 23 dates. Marine (from April to October 2001) and lagoon (from October 2001 to March 2002) recruitment seasons in the CTJB-LS. The L. vannamei cohorts are shown with 200 black circles, and each of those have an average length value ( $L M$ in $\mathrm{mm}$ ), and their corresponding age in months. The cohorts were organized and connected diagonally with 34 progression lines. Each of those was drawn between a minimum value (initial cohort) and a maximum value (terminal cohort) of LM. Cervantes-Hernández et al., 2012 [7].

personnel from the Centro Regional de Investigación Pesquera, Salina Cruz, Oaxaca, México (CRIP-SC), sampled young shrimp for determination of $L t$ and $P t$ from ten sampling stations inside CTJB-LS (Figure 1). Each sampling was done from 14 and 15 days, and young shrimp were caught using atarraya nets with mesh opening of $19 \mathrm{~mm}$, and between 1 and $6 \mathrm{~m}$. For each individual, Lt was measured from the rostrum tip to the telson end. Young shrimp were identified according to [4].

The information generated by CRIP-SC was analyzed at the Universidad del Mar, Puerto Ángel, Oaxaca, Mexico, under the 2IR1104 project. The analyses were done as follows:

\subsection{TL Estimation}

In the 34 progression lines all initial cohorts were identified (Figure 2), and after in each progression line TL was estimated taken into account the days that elapsed between initial and terminal cohort. In this case TL was expressed in months.

\subsection{Recruitment}

Estimated TL values were separated by recruitment seasons types, and with this 
information a classification neuronal model $(\mathrm{CNm})$ was conducted with three train layers (Haykin, 1999 [9]). Linear models were used in order to activate the synaptic signals and three train layers. $\mathrm{CNm}$ results were two probability trends with scale between 0 and 1 that were called dwell time inside lagoon during marine recruitment season $\mathrm{P}\left(\mathrm{TL}_{\mathrm{MR}}\right)$ and dwell time inside lagoon during lagoon recruitment season $\mathrm{P}\left(\mathrm{TL}_{\mathrm{LR}}\right)$. The first probabilistic trend was used for re-estimating the recruitment age and the second probabilistic trend was used in order to approximate youngest shrimp age inside CTJB-LS.

\subsection{Increase in Length}

White shrimp length parameters were estimated with 3,955 records of $L t$ arranged in age classes from 1 to 5 -m-olds (Et) (Figure 2). The Pitcher and McDonald, 1973 [10] model was used:

$$
L_{t e}=L_{\text {inf }} \cdot\left(1-\exp ^{\left[-k \cdot\left(E t-t_{o}\right)+((k \cdot C) /(2 \pi)) \cdot \sin \left(2 \pi \cdot\left(E t-t_{s}\right)\right)\right]}\right)+\varepsilon
$$

where $L_{t e}$ (estimated total length), $L_{\text {inf }}$ (the asymptotic length), $k$ (the metabolic growth rate in body length), $t_{o}$ (the age at zero $\mathrm{cm}$ ), $C$ (oscillations magnitude), $t_{s}$ (starting point of $C$ ), $\varepsilon$ is the estimation error of $L_{t e}$

With estimated length parameters the $L$. vannamei length trend was conducted inside CTJB-LS. This length trend was complemented with a projection towards outside CTJB-LS where the adult shrimp population reaches the oldest age. According to Taylor 1958 [11], the oldest age was estimated with:

$$
A_{0.95}=t_{o}+(2.996 / k)
$$

where the oldest age is called $A_{0.95}$ and 0.92 is the time required to obtain $95 \%$ of $L_{\text {inf }}$ value.

\section{4. $L t$-Pt Relationship}

White shrimp Lt-Pt relationship was evaluated with 6,148 records of $L t$ and $P t$. According to Ricker 1975 [12], this relationship was estimated with:

$$
P t=a \cdot L t^{b}+\varepsilon
$$

where $a$ is the intercept, $b$ is the slope, and $\varepsilon$ is the estimation error. Estimated $b$ parameter was compared with $b=3$ (isometric grow) in order to know how $L$. vannamei grew during marine and lagoon recruitment seasons. This analysis was evaluated with t-student distribution (Zar, 1999 [13]), and according to Ricker 1975 [12] when shrimp bodies grow equally in length and weight, resulted growth is isometric $(b=3)$. On the other hand, when shrimp bodies grow more in length than in weight, resulted growth type is negative allometry $(b<3)$, and the inverse is positive allometry $(b>3)$.

To estimate the parameters in the Equations (1)-(3), the Bayesian method of likelihood was used with the $\varepsilon$ fitted to log-normal distribution (Haddon, 2011 [14]). Bayesian method of likelihood was conducted with PopTools 2.7.5 software, and $\mathrm{CNm}$ was executed with StatSoft ${ }^{\oplus} 7.0$ software. 


\section{Results}

\subsection{TL Estimation}

TL values are summarized in Table 1.

\subsection{Recruitment}

Results of this section are shown in Figure 3.

For the population of $L$. vannamei inside CTJB-LS, the real age structure resulted between 1 and 4-m-olds (Figure 2). During marine recruitment season it was observed that when age increased the $\mathrm{P}\left(\mathrm{TL}_{\mathrm{MR}}\right)$ gradually descended. Estimated $\mathrm{P}\left(\mathrm{TL}_{\mathrm{MR}}\right)=0.50$ was taken into account as the midpoint of change in order to understand how young shrimp with 3-m-olds started leaving the CTJB-LS $\left(\mathrm{P}\left(\mathrm{TL}_{\mathrm{MR}}\right)>0.5\right)$, and how the rest remained inside CTJB-LS $\left(\mathrm{P}\left(\mathrm{TL}_{\mathrm{MR}}\right)<0.5\right)$. Young shrimp in 4-m-olds showed the minimal $\mathrm{P}\left(\mathrm{TL}_{\mathrm{MR}}\right)$ value, and ages $>$ 4-m-olds were not found inside CTJB-LS. Based on the aforementioned, it was concluded that young shrimp migration elapsed between 3 and 4 -m-olds, with the highest recruit flow in 4-m-olds. This last age was called the recruitment age of L. vannamei.

Table 1. Dwell times inside lagoon (TL) of young L. vannamei during marine (MR) and lagoon (LR) recruitment seasons inside CTJB-LS. With reference to Figure 2, the following are designated number to progression lines (LP), total cohorts number (TC).

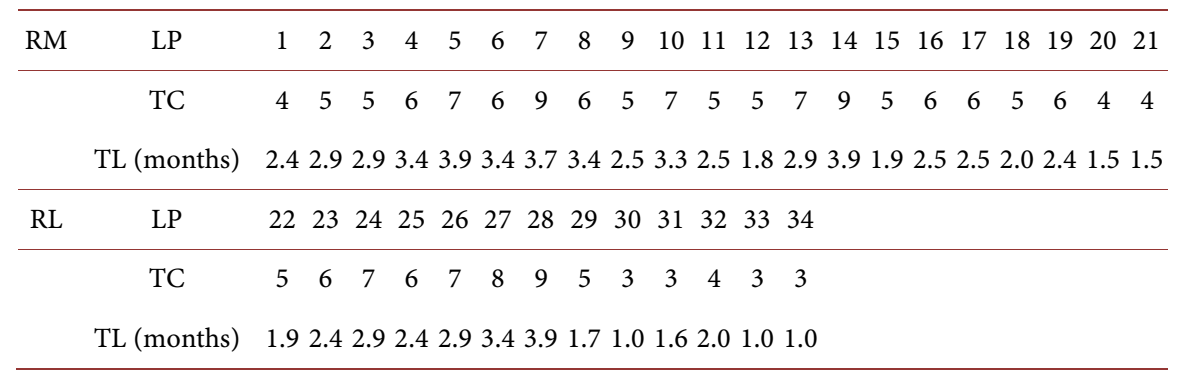

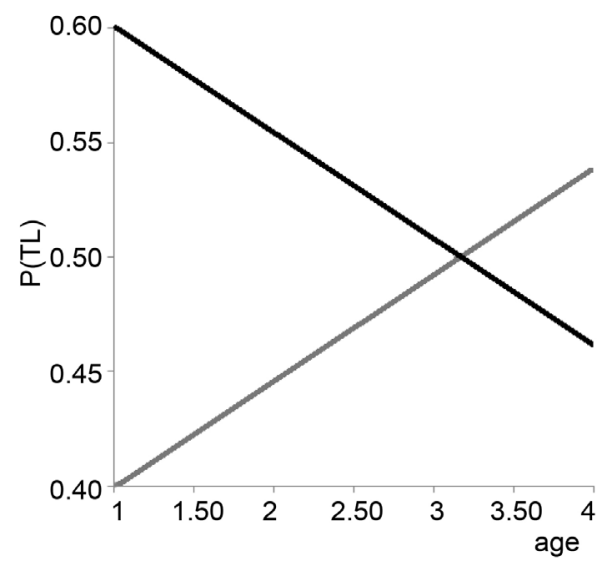

Figure 3. Dwell time inside lagoon (TL), and their probabilistic trends during marine $\mathrm{P}\left(\mathrm{TL}_{\mathrm{MR}}\right)$ (dark line) and lagoon $\mathrm{P}\left(\mathrm{TL}_{\mathrm{LR}}\right)$ (gray line) recruitment seasons in the CTJB-LS. 
During lagoon recruitment season it was observed that when age increased the $\mathrm{P}\left(\mathrm{TL}_{\mathrm{MR}}\right)$ gradually ascended. Estimated $\mathrm{P}\left(\mathrm{TL}_{\mathrm{MR}}\right)=0.50$ was taken into account as the midpoint of change in order to understand how young shrimp between 3 and 4-m-olds started to have a relevant presence inside CTJB-LS $\left(\mathrm{P}\left(\mathrm{TL}_{\mathrm{MR}}\right)>\right.$ $0.5)$, and how the rest did not show a relevant presence $\left(P\left(\mathrm{TL}_{\mathrm{MR}}\right)<0.5\right)$. Young shrimp in 1-m-old recorded the value of 0.40 in P(TLMR), and based on this it was concluded that post-larval could not be detected inside CTJB-LS until they reach 1 -m-old ( youngest shrimp age).

\subsection{Increase in Length}

Results of this section are shown in Figure 4.

The ages that frequently entered and developed inside CTJB-LS were identified between 1 and 4-m-olds (Figure 3), and for this age structure the Lt ranked from 51 to $106 \mathrm{~mm}$ (Figure 4). The $\mathrm{A}_{0.95}$ was estimated at 19-m-olds reaching the asymptotic length at $205 \mathrm{~mm}$.

\subsection{Lt-Pt Relationship}

Results of this section are summarized in Table 2 and Figure 5.

White shrimp Lt-Pt relationship resulted almost equal in both recruitment seasons $\left(\mathrm{F}=3.25, \mathrm{~F}_{0.05(1,6146)}=3.84, p>0.05\right)$. But based on estimated $b$ parameters,

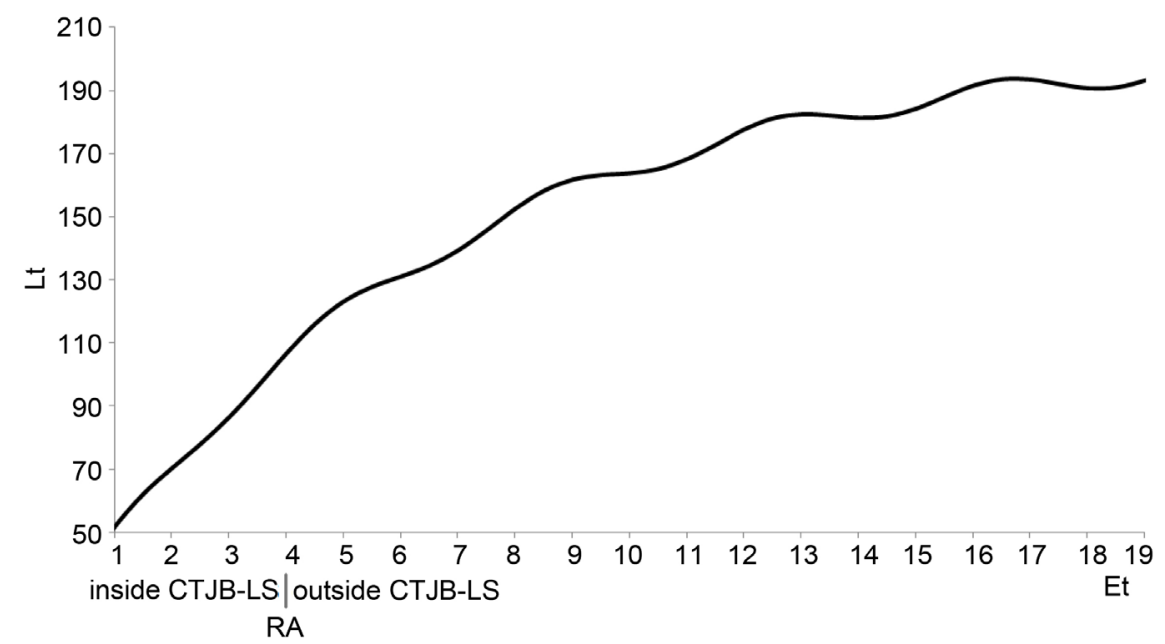

Figure 4. Complete length trend for $L$. vannamei, April $25^{\text {th }} 2001-$ March $28^{\text {th }} 2002$ period. Total length ( $L t$ in $\mathrm{mm}$ ), recruitment age ( $R A$ in months), the age structure (Et in months). Estimated length parameters: $L_{\text {inf }}=205 \mathrm{~mm}, k=0.15$ monthly, $t_{o}=-0.76 \mathrm{~mm}, C=0.65$, $t_{s}=0.25$. Final estimated model: $L_{t e}=205 \cdot 1-\exp ^{[-0.152 \cdot(E t-(-0.76))+((0.15 \cdot 0.65) /(2 \pi)) \cdot \sin (2 \pi \cdot(E t-(-0.25)))]}$.

Table 2. Estimated parameters in Lt-Pt relationship. Intercept (a), slope (b), determination $\left(r^{2}\right)$, size sample $(n)$, significance level $(p)$.

\begin{tabular}{lccccc}
\hline & $a$ & $b$ & $r^{2}$ & $n$ & $p$ \\
\hline marine recruitment season & -5.19 & 3.04 & 0.96 & 3,955 & $<0.05$ \\
lagoon recruitment season & -4.88 & 2.88 & 0.96 & 2,193 & $<0.05$ \\
\hline
\end{tabular}


it was concluded that during marine recruitment season $L t$-Pt relationship was isometric (ho: $3.04=3.00, \mathrm{t}=0.87, \mathrm{t}_{0.05(1), 3,953)}=1.64, p>0.05$ ), and during lagoon recruitment season this relationship was negative allometry (ha: $2.88<3.00, \mathrm{t}=$ $\left.10.81, \mathrm{t}_{0.05(1), 2,191}=1.64, p<0.05\right)$.

The highest biomass production was recorded inside CTJB-LS during marine recruitment season (Figures 2-6), and this was explained by the high cohorts number that reached the recruitment age with $8.4 \mathrm{~g}$ and $>106 \mathrm{~mm}$. The lowest biomass production was recorded inside CTJB-LS during lagoon recruitment season (Figures 2-6), and this was explained by the low cohorts number that reached the recruitment age with $7.6 \mathrm{~g}$ and $>106 \mathrm{~mm}$.

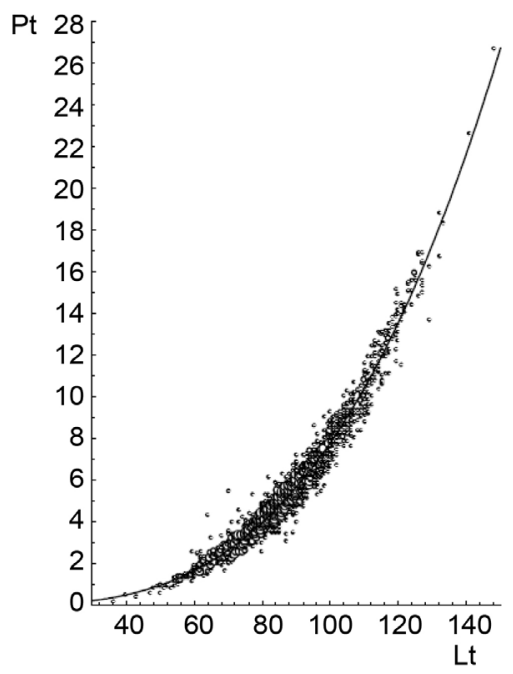

(a)

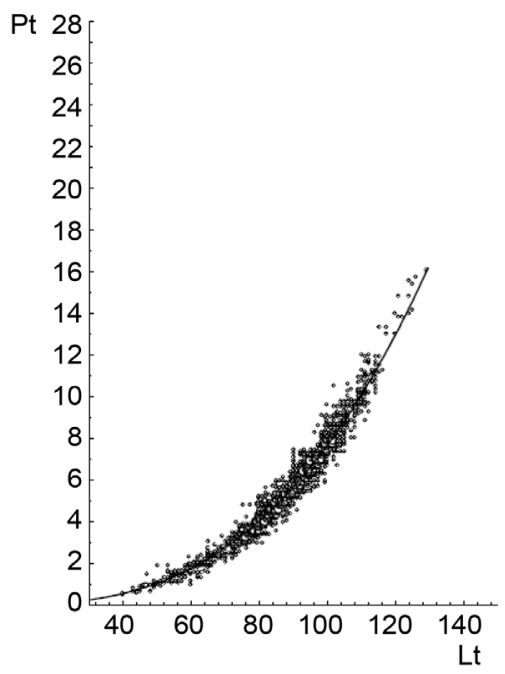

(b)

Figure 5. Lt-Pt relationship models for L. vannamei, April $25^{\text {th }} 2001-M a r c h ~ 28^{\text {th }} 2002$ period. Total length ( $L t$ in $\mathrm{mm}$ ), total weight ( $P t$ in gr). Estimated model for marine recruitment season: $P t=-5.19 \cdot L t^{3.04}+\varepsilon$, and estimated model for lagoon recruitment season: $P t=-4.88 \cdot L t^{2.88}+\varepsilon$

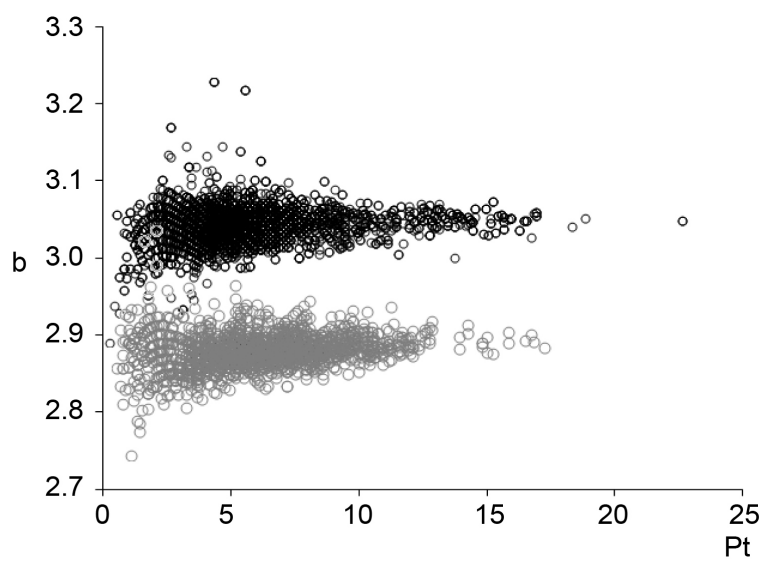

Figure 6. Total weight ( $P t$ in gr) vs. $b$ parameter. During marine recruitment season $L t-P t$ relationship was isometric ( $b=3$, black pints), and shrimp bodies grow equally in length and weight. During lagoon recruitment season $L t$-Pt relationship was negative allometric ( $b<3$, gray points), and shrimp bodies grow more in length than in weight. 


\section{Discussion}

\subsection{TL Estimation and Recruitment}

The region of GT is influenced by northerly winds from the Gulf of Mexico, which produce intense upwelling during winter Tehuanos seasons between November and February (Fernández-Álamo et al., 2000 [15]). The upwelling process generates an ascension of cooler deep water and an elevated concentration of nutrient due to the rupture of the thermocline (González-Silvera et al., 2004 [16]). These characteristics induce a complex oceanographic pattern with cyclonic and anticyclonic eddies that affect the concentration of chlorophyll $a$ (Cl-a), primary productivity, and spatial distribution of organisms (Gallegos-García and Barberán-Falcón, 1998 [17]; Monreal-Gómez and Salas de León, 1998 [18]; Farber-Lorda et al., 2004 [19]). Lara-Lara et al., 1998 [20] mentioned that outside winter Tehuanos seasons (during rainy seasons between May and October), in the region of GT lower $\mathrm{Cl}-\mathrm{a}$ and primary productivity values were documented, and these were generated mainly by the local fluvial discharge.

As was established for L. vannamei, marine recruitment seasons spanned from April to August, with the highest recruit flow during June/July. These seasons coincided with the rainy seasons, when lower reproductive activity was documented. Reproductive seasons spanned from July to November, with the highest post-larvae flow during October (Cervantes-Hernández et al., 2008 [4]).

Inside lagoon systems rainfall and fluvial discharge impose osmoregulatory limitations that stimulate young shrimp migration toward marine environments (Ruello, 1973 [21]; Cruz-Orozco and Ley-Lou, 1980 [22]; García and Le Reste, 1986 [23]; Cervantes-Hernández, 2015 [24]). Browder and Moore 1981 [25] mentioned that fresh water flow into coastal body of water increases shrimp production because mineral, organic matter and turbidity increases (Penn and Caputi, 1986 [26]), and salinity with water temperature are reduced. García and Le Reste 1986 [23] indicated that environmental changes might delay or hurry shrimp migration.

In the Bank of Campeche, Mexico, Cervantes-Hernández 1999 [27] showed that marine recruitment of pink shrimp Farfantepenaeus duorarum (Burkenroad 1939) has a relationship with accumulated rainfall and fluvial discharge since 2 and 1 months, respectively, before maximum recruitment occur. Similar results were documented by Gracia and Soto 1990 [28] in white shrimp Litopenaeus setiferus (Linnaeus 1767).

In this study, it was concluded that young recruits migration toward outside CTJB-LS elapsed between 3 and 4-m-olds, with the highest recruit flow in 4-m-olds. Thus this last age was called the recruitment age of $L$. vannamei (Figure 3). The young of $L$. vannamei from 83 to $120 \mathrm{~mm}$ were documented as present marine environment in front of the Mar Muerto, CTJB-LS, Chantuto-Panzacola y Carretas-Pereyra lagoon systems, Oaxaca-Chiapas, Mexico (Figure 1) (Ramos-Cruz, 2011 [29]). Specific ages for these sizes were not reported but based on Figure 4, it was suggested that these ages should be between 
3 and 5-m-olds.

A recruitment age in 4-m-olds was documented for brown shrimp Farfantepenaeus californiensis (Holmes 1900) in GT (Cervantes-Hernández, 2008 [1]; Cervantes-Hernández et al., 2008 [4]), and brown shrimp Farfantepenaeus aztecus (Ives, 1891) in Tamaulipas-Veracruz region, Gulf of Mexico (Cervantes-Hernández, 2015 [24]). The young of $L$. vannamei and $F$. aztecus with 3 -m-olds were documented as present in the marine environments from gulfs of GT and Mexico (Cervantes-Hernández et al., 2008 [4]; Cervantes-Hernández, 2015 [24]). Due to its lower finishing mortality rates (F) and abundances these ages were reported underexploited, and partially recruited to the adult population. Monthly F values were estimated at $\mathrm{F}=0.01$ (Ramos-Cruz et al., 2006 [3]), and $\mathrm{F}=0.02$ (Cervantes-Hernández, 2015 [24]), respectively. In this study, this specific age was considered such as the minimum recruitment age inside CTJB-LS.

\subsection{Increase in Length and Lt-Pt Relationship}

Inside CTJB-LS the recruitment age of $L$. vannamei was reported between 4.5 and 5-m-olds (Cervantes-Hernández et al., 2012 [7]), but in this study ages > 4-m-olds were not found in this lagoon system. These specific ages were considered as the maximum recruitment ages that can be found outside CTJB-LS (Ramos-Cruz, 2011 [29]), completely recruited to the adult population (Lt 125 mm y Pt 14 g) (Figure $4 \&$ Figure 5). The aforementioned was true, because the sexual maturity age is generally reached between 6 and 7 -m-olds as in cases of $F$. californiensis (Cervantes-Hernández, 2008 [1]), F. aztecus (Cervantes-Hernández, 2015 [24]) y L. vannamei (Cervantes-Hernández et al., 2008 [4]). For those species the entire population is sexually mature between 11 and 16-m-olds.

Based on the information mentioned in the literature a new conclusion was done. In brief, in optimal environmental conditions (mainly rainfall and fluvial discharge), in CTJB-LS young recruits migration occurs during marine recruitment seasons between 3 and 5-m-olds, with the highest recruit flow in 4-m-olds. Environmental changes might delay (dominant ages in 5-m-olds) or hurry (dominant age in 3-m-olds) young recruits migration. The first case was documented by different authors, and this was explained due to excesses in the built of reservoirs and environmental pollution (Cervantes-Hernández, 2015 [24]; Cervantes-Hernández et al., 2012 [30]; 2017 [31]). The 5-m-olds age was documented in relation with delay young recruits migration (Solana-Sansores et al., 1989 [32]; Hannah, 1999 [33]). The second case has relationship with the prolonged development of rainfall and fluvial discharge periods.

As was established, during marine recruitment season the recruitment age recorded $8.4 \mathrm{~g}$ with $L t$ at $106 \mathrm{~mm}$, and during recruitment season, the Pt reduced by $0.8 \mathrm{~g}$ at the same $L t$ value (Figure 6). Ramos-Cruz (2011) [29] recorded $6.0 \mathrm{~g}$ in the youngest recruits of $L$. vannamei. Specific age for this weight was not reported but based on Figure 4, it was suggested that this age should be 3-m-olds 
with $L t$ at $80 \mathrm{~mm}$. This author did not consider differences between marine and lagoon recruitment seasons in order to estimate the following $L t$-Pt relationship model: $P t=0.0000283 \cdot L t^{3.22}+\varepsilon$. The author did not conclude on this model but considering that $b=3.22$, it was suggested that during study period $L t$ - $P t$ relationship was positive allometry $(b>3)$.

Since 1976 in lagoon systems located in GT, the artisanal catch of L. vannamei and F. californiensis has been done with atarraya nets with mesh opening of 25.4 mm (Ramos-Cruz, 2011b [8]). PESCA 1997 [34] indicated that the artisanal catch must be done with atarraya nets with mesh opening of $38.1 \mathrm{~mm}$, but this mesh opening really have never been used in GT. With the first mesh opening mentioned by [8] the length catch ranked from 60 and $120 \mathrm{~mm}$, and with suggested ages between 1.5 and 4.5-m-olds (Figure 4). On the other hand, with an atarraya nets with mesh opening $<25.4 \mathrm{~mm}$ the length catch was $<80 \mathrm{~mm}$ ( $<3$-m-olds). It was considered that these mentioned data were not correct because the artisanal catch of this study was obtained with mesh opening of 19 $\mathrm{mm}$, and the age catch ranked from 1 and 5-m-olds. Thus, it was concluded that atarraya nets with mesh opening between 19 to $25.4 \mathrm{~mm}$ generate the same range of catch for shrimp length and age. Ramos-Cruz, 2011 [8] reported in activity atarraya nets with mesh opening from 9.5 to $25.4 \mathrm{~mm}$.

The discussion about which mesh opening should be used to protect shrimp recourse in GT is open, and in this study we did not recommend a mesh opening to use inside lagoon systems because we do not have a scientific base to support this, instead shrimp artisanal catch can carry on like ever, but the following should be taken into account:

1) Atarraya nets with mesh opening of $25.4 \mathrm{~mm}$ can be used during complete lagoon recruitment seasons because as was established before, in CTJB-LS biomass production was lower. This same should be done in the other lagoon systems located in GT.

2) During marine recruitment seasons atarraya nets with mesh opening of $25.4 \mathrm{~mm}$ only can be use from April to May when biomass production and young recruits migration begin to increase. All fishing methods shall be prohibited from June to July because in this period maximum young recruits migration occurs (Figure 2). Details in the literature (Cervantes-Hernández, 1999 [27]; 2008 [1]; 2015 [24]; Cervantes-Hernández et al., 2008 [4]; 2012 [7]; 2017 [31]).

The marine shrimp fishery has been regulated in Mexican Pacific through closure systems, and these were documented as follow: from July to September (between 1979 and 1987), from May/April to September (between 1993 and 1997) (Cervantes-Hernández et al., 2008 [4]), from April to September 1999, and afterwards of 2001 from March/April to September (INAPESCA, 2007 [35]). In GT, closure periods have not worked because these periods were focused on protecting marine recruitment seasons, and lagoon recruitment seasons were only partially included. In the literature if was found that $L$. vannamei reproductive seasons spanned from June to November, with the highest post-larvae flow 
during October (Cervantes-Hernández et al., 2008a [4]). In the case of $F$. californiensis reproductive seasons spanned July to February, with the highest post-larvae flow during October/November (Cervantes-Hernández, 2008 [1]; Cervantes-Hernández et al., 2008 [4]).

The last authors mentioned proposed a new closure system to protect shrimp reproductive seasons exclusively in GT. This closure system was reported from June/July to October, and afterward this was ratified by Cervantes-Hernández et al. 2017 [31] from July to November. To manage the artisanal shrimp catch, the second choice should be better because during July a lagoon closure can be established inside lagoon systems located in GT. This new proposal will allow for artisanal fishermen to use atarraya nets with mesh opening of $25.4 \mathrm{~mm}$ during complete June, and they will obtain a good biomass production level as support (Figure 6).

From the beginning, the results published on marine closure system changes in GT were not accepted by the fishery community in Oaxaca because those studies did not include lagoon recruitment information in their fishery models. At present, shrimp fishery in GT is reported on a critical level of overexploitation (Cervantes-Hernández et al., 2006 [36]). A lagoon closure was proposed by Barrera-Huerta in 1976 [37], and this was not taken into account due to a lack of ecological, biological and fishery analysis. Now, L. vannamei fishery has complete population analysis in order to influence possible closure system changes. This information is a guide to plan $F$. californiensis fishery because both fisheries in GT reproduce almost at the same time.

\section{References}

[1] Cervantes-Hernández, P. (2008) Method to Obtain Indices of Abundance in the Population of Brown Shrimp from the Gulf of Tehuantepec, Oaxaca, Mexico. Revista de Biología Marina y Oceanografía, 43, 111-119. https://doi.org/10.4067/S0718-19572008000100011

[2] Gracia, A., Vázquez-Bader, A.R., Arreguín-Sánchez, F., Schultz-Ruiz, L.E. and Sánchez, J.A. (1997) Ecología de camarones peneidos. En: Flores-Hernández, D., Sánchez-Gil, P., Seijo, J.C. and Arreguín Sánchez, F., Eds., Análisis y diagnóstico de los recursos pesqueros críticos del Golfo de México, EPOMEX Serie Científica, Campeche, México, 127-144.

[3] Ramos-Cruz, S., Sánchez-Meraz, B., Carrasco-Ayuso, F. and Cervantes-Hernández, P. (2006) Estimation of the Natural Mortality Rate of Farfantepenaeus californiensis (Holmes, 1900) and Litopenaeus vannamei (Boone, 1931), in the Coastal Zone of the Gulf of Tehuantepec, Mexico. Revista de Biología Marina y Oceanografía, 41, 221-229. https://doi.org/10.4067/S0718-19572006000200010

[4] Cervantes-Hernández, P., Gallardo-Berumen, M.I., Ramos-Cruz, S., Gómez-Ponce, M.A. and Gracia, A. (2008) Analysis of the Closed Seasons in the Marine Shrimp Exploitation of the Gulf of Tehuantepec. Revista de Biología Marina y Oceanografía, 43, 285-294.

[5] Cervantes-Hernández, P., Sánchez-Meraz, B., Frías-Velasco, A., Serrano-Guzmán, J.S., Ramos-Cruz, S. and Gracia, A. (2008) Annual Abundance Variation of Farfantepenaeus californiensis (Holmes, 1900) in the Gulf of Tehuantepec. Hidrobiológica, 18, 215-226. 
[6] Cervantes-Hernández, P. and Egreny-Valdez, A. (2013) Variation of Shrimp Total Catch Related to the Geographic Distribution of Sediments at Fishing Zone 90, Gulf of Tehuantepec, Oaxaca, Mexico. Hidrobiológica, 23, 111-123.

[7] Cervantes-Hernández, P., Gómez-Ponce, M.A. and Torres-Hernández, P. (2012) Marine and Lagoon Recruitment of Litopenaeus vannamei (Boone, 1931) (Decapoda: Penaeidae) in the "Cabeza de Toro-La Joya buenavista" Lagoon System, Chiapas, Mexico. CICIMAR Oceánides, 27, 51-58.

[8] Ramos-Cruz, S. (2011) Selectividad y estimación de un tamaño mínimo de malla para las atarrayas camaroneras en la laguna Mar Muerto, Oaxaca-Chiapas, México, con implicaciones para el manejo de la pesquería. Ciencia Pesquera, 19, 47-57.

[9] Haykin, S. (1999) Neural Networks. A Comprehensive Foundation. Prentice Hall, Upper Saddle River, 842.

[10] Pitcher, T.J. and McDonald, P.D.M. (1973) Two Models for Seasonal Growth in Fishes. Journal of Applied Ecology, 10, 599-606. https://doi.org/10.2307/2402304

[11] Taylor, C. (1958) Cod Growth and Temperature. Journal du Conseil/Conseil Permanent International pour l'Exploration de la Mer, 23, 366-370. https://doi.org/10.1093/icesjms/23.3.366

[12] Ricker, W. (1975) Computation and Interpretation of Biological Statistic of Fish Population. Bulletin of the Fisheries Research Board of Canada, 191, 1-382.

[13] Zar, H.J. (1999) Biostatistical Analysis. Prentice Hall, Upper Saddle River, 663.

[14] Haddon, M. (2011) Modelling and Quantitative Methods in Fisheries. Chapman and Hall CRC Press, London, 405.

[15] Fernández-Álamo, M.A., Sanvicente-Añorve, L. and Alameda De-La-Mora, G. (2000) Copepod Assemblages in the Gulf of Tehuantepec, Mexico. Crustaceana, 73, 1139-1153. https://doi.org/10.1163/156854000505137

[16] González-Silvera, A., Santamaria E., Millán-Nuñez, R. and Manzo-Monrroy, H. (2004) Satellite Observations of Mesoscale Eddies in the Gulfs of Tehuantepec and Papagayo (Eastern Tropical Pacific). Deep-Sea Research II: Topical Studies in Oceanography, 51, 587-600.

[17] Gallegos-García, A. and Barberán-Falcón, J. (1998) Surgencia eólica. En: Tapia-García, M., Ed., El Golfo de Tehuantepec. El ecosistema y sus recursos, Universidad Autónoma Metropolitana-Iztapalapa, México, 27-34.

[18] Monreal Gómez, M.A. and Salas, D.A. (1998) Dinámica y estructura termohalina. En: Tapia-García, M., Ed., El Golfo de Tehuantepec. el ecosistema y sus recursos. Universidad Autónoma Metropolitana-Iztapalapa, México, 13-26.

[19] Farber-Lorda, J., Lavin, M.F. and Guerrero-Ruíz, M.A. (2004) Effects of Wind Forcing on the Trophic Conditions, Zooplankton Biomass and Krill Biochemical Composition in the Gulf of Tehuantepec. Deep-Sea Research II: Topical Studies in Oceanography, 51, 601-614.

[20] Lara-Lara, J.R., Robles-Jarero, E.G., Bazán-Guzmán, M.C. and Millán-Nuñez, E. (1998) Productividad del fitoplancton. En: Tapia-García, M., Ed., El Golfo de Tehuantepec. El ecosistema y sus recursos, Universidad Autónoma Metropolitana-Iztapalapa, México, 51-58.

[21] Ruello, N. (1973) The Influence of Rainfall on the Distributions and Abundance of the School Prawn Metapenaeus macleayi in the Hunter River Region (Australia) Marine Biology, 23, 221-228. https://doi.org/10.1007/BF00389488

[22] Cruz-Orozco, R. and Ley-Lou, F. (1980) Estudio del sistema fluvio-lagunar-deltáico de la Región de Campeche, Tabasco, en particular de la Laguna de Términos y áreas 
adyacentes, para su mejor uso y aprovechamiento. Consejo Nacional de Ciencia y Tecnología, México, 61.

[23] García, S. and Le-Reste, L. (1986) Ciclos vitales, dinámica, explotación y ordenación de las poblaciones de camarones peneidos costeros. Organización de las Naciones Unidas para la Alimentación y la Agricultura, Roma, 180.

[24] Cervantes-Hernández, P. (2015) Modelación de las fluctuaciones de la abundancia del camarón café Farfantepenaeus aztecus (Ives 1891) Tesis de Doctorado, Instituto de Ciencias del Mar y Limnología, UNAM. http://132.248.9.195/ptd2015/marzo/098850345/Index.html

[25] Browder, J. and Moore, D. (1981) A New Approach to Determining the Quantitative Relationship between Fishery Production and Flow of Fresh Water to Estuaries. In: Cross, R. and Williams, D., Eds., Proceedings of the National Symposium on Freshwater Inflow to Estuaries, Vol. 1, United States Fish and Wildlife Service, Office of Biological Services, 403-430.

[26] Penn, J.W. and Caputi, N. (1986) Spawning Stock-Recruitment Relationships and Environmental Influences on the Tiger Prawn Penaeus esculentus Fishery in Exmouth Gulf, Western Australia. Australian Journal of Marine and Freshwater Research, 37, 491-505. https://doi.org/10.1071/MF9860491

[27] Cervantes-Hernández, P. (1999) Relaciones stock-reclutamiento del camarón Farfantepenaeus duorarum en el Banco de Campeche. Tesis de Maestría, Instituto de Ciencias del Mar y Limnología, UNAM. http://132.248.9.195/pd1999/274584/Index.html

[28] Gracia, A. and Soto, L. (1990) Population Study of the Penaeid Shrimp of Términos Lagoon, Campeche, México. Anales del Instituto de Ciencias del Mar y Limnología UNAM, 17, 241-255.

[29] Ramos-Cruz, S. (2011) Relaciones biométricas del camarón blanco Litopenaeus vannamei Boone 1931 (Decapoda, Penaeidae), para la región del Golfo de Tehuantepec, México. CICIMAR Oceánides, 26, 71-75.

[30] Cervantes-Hernández, P., Gallardo-Berumen, M.I. and Serrano-Guzmán, S.J. (2012) Exploitation and Distribution of Artisanal Shrimp Catch in the Huave Lagoon System, Oaxaca, Mexico. Revista Ciencias Marinas y Costeras, 4, 67-81.

[31] Cervantes-Hernández, P., Pérez-Vives, E. and Gómez-Ponce, M.A. (2017) Nesting and Exploitation of the Olive Ridley Sea Turtle at Escobilla Beach, Oaxaca, Mexico. Revista Ciencias Marinas y Costeras, 9, 91-107. https://doi.org/10.15359/revmar.9-1.6

[32] Solana-Sansores, R., Arregín-Sánchez, F., Castro, R. and Medellín, M. (1989) Exploración de técnicas multivariadas para uso en el estudio de la dinámica poblacional de especies sujetas a explotación pesquera: el caso del camarón café (Penaeus aztecus Ives 1891) del noroeste del Golfo de México. Boletin del Instituto Oceanografico de Venezuela, 28, 245-252.

[33] Hannah, R.W. (1999) A New Method for Indexing Spawning Stock and Recruitment in Ocean Shrimp, Pandalus jordani, and Preliminary Evidence for a StockRecruitment Relationship. Fishery Bulletin, 97, 482-494.

[34] PESCA (1997) NOM-002-PESC-1993. Norma Oficial Mexicana para ordenar el aprovechamiento de las especies de camarón en aguas de jurisdicción federal de los estados unidos mexicanos.

http://sagarpa.gob.mx/normateca/normateca2/10\%20NOM\%20002\%20311293.pdf

[35] INAPESCA (2007) Análisis poblaciones de camarón del litoral del Pacífico para implementar la veda durante el 2007. 
http://www.inapesca.gob.mx/portal/publicaciones/dictamenes/doc_details/154-anal isis-poblaciones-de-camaron-del-litoral-del-pacifico-para-implementar-la-veda-dur ante-el-2007

[36] Cervantes-Hernández, P., Ramos-Cruz, S. and Gracia, A. (2006) Evaluation of the State of the Shrimp Fishery in the Gulf of Tehuantepec. Hidrobiológica, 16, 233-239.

[37] Barrera-Huerta, R. (1976) Algunos aspectos a considerar para la determinación de vedas, apertura y cierre de tapos y reglamentación de la luz de malla de las atarrayas de pesca de camarón en las lagunas y marismas del estado de Oaxaça. Conferencia en biología y dinámica poblacional de camarones Vol. 1, Guayanas, Sonora, México, $1,124-130$. 